\section{GMO fudge at BIA bash}

The UK government and UK industry continue to fudge in harmony over genetically modified food and crops. Hundreds of besuited and bespangled diners at the UK Bioindustry Association's Annual Gala dinner held at the end of January listened as Marjorie "Mo" Mowlam, the minister responsible for ensuring coherent policy in biotechnology, reconfirmed the government's position of neutrality. In what sounds suspiciously like a recipe for procrastination, Mowlam said that the government's two advisory bodies-the Human Genetics Commission and the Agriculture and Environment Biotechnology Commissionwould "identify sensitive issues early on, consult widely, and seek expert advice from both sides of the debate." She did, however, urge those in the industry to "speak up more loudly in the debate" surrounding biotechnology. "I would like to see the biotechnology industry, and those of you in the science community, play a bigger role in building understanding and confidence in this technology," she said. Her comments were, however, in many respects more upbeat than those of Chris Evans, maverick chairman of the investment group Merlin Biosciences. In a speech that drew laboriously on The Best Man's Book of Bad Taste Jokes, Evans delivered his speech of thanks at the end of the dinner as a stream of personal barbs directed largely at hapless individuals within the industry. More significantly, though, Evans also suggested that the agricultural and environmental interests in biotechnology should, in effect, be cast adrift, leaving a streamlined health care sector ("which is where all the real money and interest is anyway") to cruise unhindered toward a bright future. Fortunately, though, only UK Prime Minister Tony Blair regards Evans as a spokesperson for UK biotechnology.

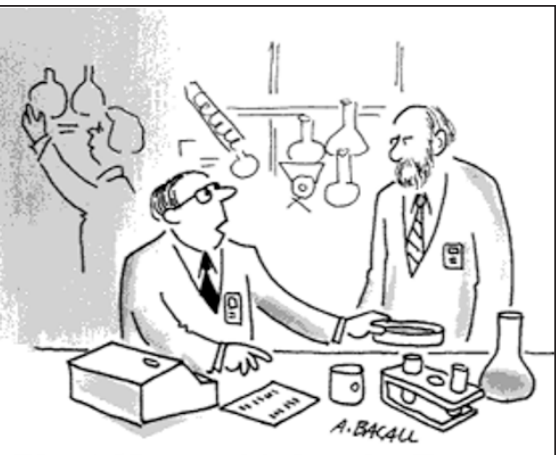

"I inserted five genes into rice grains. Three genes trigger the rice to produce beta-carotene and the other two genes cause the rice to become fried in the presence of an egg roll."

\section{Japan okays stem cells}

The bioethics committee of Japan's Science and Technology Council (Tokyo) has approved research involving the use of embryonic stem cells, citing its potential applications in the development of therapeutics for such diseases as leukemia and Parkinson's disease. The decision and the speed at which it was reached reflect the impending launch of a national research institute for regeneration medicine later this year. The new institute, which will carry out research on the development, differentiation, and regeneration of cells and tissue, is one of Japan's key life science projects for fiscal year 2000. Like other leading-edge biological projects-such as the new institutes for single nucleotide polymorphisms and plant genome research, also scheduled to be launched this year (Nat. Biotechnol., 17, 744-745)—it will be overseen by the Institute of Physical and Chemical Research (Saitama Prefecture). The bioethics committee plans to draw up new guidelines for embryonic stem cell research by the end of March, including regulations to protect the privacy of donors of fertilized eggs (from which stem cells are created). According to the committee's preliminary report, fertilized eggs would be obtained only from donors who have received infertility treatment.

AS

\section{Support for agbiotech}

More than 1,000 scientists from around the world have signed a petition in support of agricultural biotechnology. The statement was released at a press briefing held in Montreal during the recent Biosafety Protocol meeting (see page 253). According to the petition, "recombinant DNA techniques constitute powerful and safe means for the modification of organisms and can contribute substantially in enhancing quality of life." CS Prakash, director of the Center for Plant Biosafety Research at Tuskegee University (Tuskegee, AL) and who authored the petition, says the recent controversy over genetically modified foods has been an "eye-opener" for the biotech community, showing scientists that they need to "come out of their ivory towers" to explain their work to the public. The statement urges policymakers to use "sound scientific principles in the regulation of products produced with recombinant DNA, and to base evaluations of those products upon the characteristics of those products, rather than on the processes used in their development." Prakash says he hopes the petition will show the world, including regulators, policy makers, the media, and-ultimatelyconsumers, that there is "solid science behind GM food development.”

\section{Boost for Dutch biotech}

Dutch Economy Minister Annemarie Jorritsma has announced the allocation of Guilders 100 million ( $\$ 45$ million) to boost Dutch biotechnology under a new five-year "life science action plan," presented to the parliament in February. This set of five key measures, which should be operational by the middle of this year, is an attempt to regain a leading position in worldwide biotechnology. The biotech industry in the Netherlands has lost momentum in the past ten years, with the decreasing number of biotech companies reducing its rank from second to seventh among European countries involved in biotech, according to Ernst \& Young's European Life Sciences '99 report. Part of the new money will be used as venture capital to compensate for the current lack of seed capital, boost start-up financing, and create five new incubators. In addition, a "biopartner" operating platform comprising scientists, industrialists, and investors has been formed with the aim of creating 75 new biotech companies in the next five years. (55 small biotech companies currently exist.) $\$ 6.7$ million of the $\$ 45$ million has been allocated to the platform, which will be headed by Gerard van Beynum, vice president of corporate communication and strategy at the biopharmaceutical company Pharming (Leiden).

$S L$

\section{Functional map completed}

On February 10, Curagen (New Haven, CT) announced the completion of the first functional genomics map of an entire genome. The company, in collaboration with Stanley Fields at the University of Washington (Seattle), has performed a comprehensive two-hybrid analysis of protein interactions in the yeast Saccharomyces cerevisiae - the first time an analysis of the protein interactions of a complete genome has been attempted. However, many in the field note that not all possible pairwise interactions are expected to be detected with this method. Nevertheless, the news prompted an immediate $24 \%$ rise in Curagen share price. Curagen's CEO Jonathon Rothberg explains that the yeast map will function as a framework onto which a functional protein map of Drosophila (currently underway) will be layered. The intention is to draw correlation between these layers and a similar map of the entire human genome, which is set to follow 24 months after the sequence is publicly available. "No other company in the world is doing each of the layers," says Rothburg, "We're the only one that has the synergistic approach." 